\title{
Optimization of the Proportions for Banana Based Weaning Flour by Variation in Ingredients
}

\author{
B. Oshaba ${ }^{1}$, J. Kigozi ${ }^{*}$ and A. Atukwase ${ }^{2}$ \\ ${ }^{1}$ Department of Agricultural and Biosystems Engineering, Makerere University, \\ P.O. Box 7062 Kampala, Uganda \\ 2Department of Food Science and Technology, Makerere University, \\ P.O. Box 7062 Kampala, Uganda \\ *Corresponding author details: J. Kigozi; jbulyakigozi@yahoo.com
}

\begin{abstract}
The transformation of green banana flour by making various products is an alternative to add value to banana flour hence reducing postharvest losses in banana. This study aimed at optimization of the proportions for the banana based weaning flour for infants between 6 to 24 months of age by variation in ingredients. The composite flour consisted of banana flour (B), soybean flour (S) and grain amaranth flour (A). NutriSurvey2007 software was used to optimize the proportions for the ingredients in accordance with the recommended nutrient requirement for weaning children 6-24 months of age. The formulations developed were 60B:30S:10A, 60B:35S:05A, 55B:30S:15A, 55B:35S:10A, 50B:30S:20A and 50B:35S:15A. The different composites were analyzed for proximate composition, physical- chemical and sensory properties. The data was then fed into the D-Optimal mixture design under Design Expert software 11 to come up with the most desirable formulation that meets the nutrient requirement for weaning children 6-24 months of age. The optimum formulation was found to be $54.4 \mathrm{~B}: 35 \mathrm{~S}: 10.6 \mathrm{~A}$ with a gross energy of $366.63 \mathrm{Kcal}$, protein content of $23.15 \%$, Carbohydrate content of $52.23 \%$, fat content of $7.23 \%$, fiber content of 3.02 , ash content of 4.07 , moisture content of 10.3 , in vitro protein digestibility of $78.97 \%$, acceptability of 6.8 and desirability of 5.3 .
\end{abstract}

Keywords: optimization; formulation; weaning; flour; banana

\begin{abstract}
INTRODUCTION
Banana is one of the most popular fruit and one of the world's most important staple foods along with rice, maize and wheat. In 2011, the production of banana was 107 million metric tons in more than 130 countries on $0.1 \%$ of the world's agricultural area (1). In the Sub- Saharan region, Uganda is the largest producer of bananas and plantains with the highest per capita consumption of 191 kg per year (2) in the whole world. The estimated production of banana in Uganda is 4.5 million tons (3). Banana is an important staple food for more than $70 \%$ of Uganda's population and is grown by $72 \%$ of farmers on an average plot size of one hectare (4).
\end{abstract}

However, bananas are highly perishable and subject to first deterioration as their moisture content and high metabolic activity persist after harvest (5). According to (6), the postharvest losses in banana range between 24$45 \%$. The shelf life of banana and thus its value addition can be improved by drying. Drying is one of the oldest technologies in the processing of agricultural produce and a lot of research has been carried out on the drying of different crops. Drying removes water from food to a level that microbial spoilage and deterioration reactions are greatly minimized (7). Drying is a complex process in which heat and mass transfer occur simultaneously. It is important to understand the parameters controlling this complex process and to understand the drying behavior of a given product for use in improving the existing drying systems, controlling the drying process and improving on the quality of the dried product. After the banana is dried, it can then be milled into banana flour or used as banana chips. When milled, banana flour is used to make various products such as bread, cakes, cookies, pasta, cereal bars and porridges (8)(9)(10). Banana flour can be processed into various and desirable products so as to achieve the following objectives; diversify the usage or utility, ensure off-season availability, create convenience in nutrition and to significantly reduce the bulkiness and storage space requirement (11). Much as green banana flour has got a high percentage of resistant starch making it a good source of energy, it is deficient in key nutrients for weaning children such as proteins and vitamins. To address this problem, nutrient rich plant sources such as soybean, sesame, Brazil nut, cowpea and grain amaranth have been added to banana flour to improve its nutrient content. This research aimed at incorporation of soybean and grain amaranth into the banana flour to produce a banana-based flour for weaning children. Soybean consumption is increasing worldwide due to the acclaimed healthy benefits (12). The soybean seed primarily provides protein and oil. The protein content of soybean on average is $40 \%$ and its oil content is $20 \%$ (13). Soybean is rich both in essential and non- essential amino acids. Soybean protein is exceptionally rich in lysine and can serve as valuable supplement to cereal foods where lysine is a limiting factor. Grain amaranth as another ingredient in the process contains high quality protein, twice the level of calcium in milk, higher in potassium, phosphorous, zinc, vitamin A, E and folic acid (14) which are essential for rapid growth of children. 
Consumption of grain amaranth has been reported to have nutritional and healthy benefits ranging from a general improvement in well-being to prevention and improvement of specific ailments and symptoms including recovery of severely malnourished children and an increase in the body mass index of people formerly wasted by HIV/AIDS (15).

\section{MATERIALS AND METHODS}

\section{Sample Preparation}

Banana flour was produced from the raw mature banana fruit following the method described by (16). The bananas were peeled using stainless steel knives under $0.2 \%$ sodium metabisulphite for 5 minutes to prevent browning. They were sliced into $2 \mathrm{~cm}$ thick slices using a grater. The slices were dried in hybrid oven at $60{ }^{\circ} \mathrm{C}$ for 5 hours. The dried slices were then milled into flour using a wonder mill. The flour was sieved through a $300 \mathrm{~nm}$ sieve. Grain Amaranth was purchased from the National Crops Resources Research institute Namulonge.
The grains were sun dried for 8 hours and were milled using a wonder mill. The flour was sieved through a $300 \mathrm{~nm}$ sieve. Soybean seeds were purchased from Kalerwe market in Kampala. The seeds were sorted, milled and sieved through a $300 \mathrm{~nm}$ sieve. The three types of flour were differently packaged in plastic polyethene bags and kept for further use.

\section{Product Development}

Six formulations of the different flour composites of Banana (B), Soybean (S) and Grain Amaranth (A) were developed using NutriSurvey2007 software according to Table 1 below. The formulations were designed in such a way to meet the nutrient requirements for weaning children between 6-24 months of age. The different formulations were taken to the laboratory at the School of Food Technology, Nutrition and Bio- Engineering Makerere University for further analysis.

TABLE 1: Formulations for the Anana Based Weaning Flour According to Nutrisurvey 2007

\begin{tabular}{cccccc}
\hline Sample no. & Banana & Soybean & Grain Amaranth & Energy (kcal) & Protein (g) \\
\hline 1 & 60 & 30 & 10 & 336.4 & 14.1 \\
2 & 60 & 35 & 05 & 338.7 & 15.1 \\
3 & 55 & 30 & 15 & 340.5 & 14.6 \\
4 & 55 & 35 & 10 & 342.7 & 15.6 \\
5 & 50 & 30 & 20 & 344.5 & 15.1 \\
6 & 50 & 35 & 15 & 346.7 & 16.2 \\
\hline
\end{tabular}

\section{Determination Proximate Composition}

Moisture content was determined by oven drying method (17), ash content was determined by igniting a dried, ground sample in a furnace at $450{ }^{\circ} \mathrm{C}(18)$. Crude protein content was determined using kjedahl method as described by (19); crude fat was determined by Soxhlet apparatus as described by (17), dietary fiber by gravimetric method while carbohydrate content was determined by the difference method according to (20).

\section{Determination of physical properties}

Water absorption capacity, foaming capacity, swelling power and bulk density were assessed as described by $(21$, 22). Pasting properties were determined using the Rapid visco analyser as described by (23).

\section{Acceptability test}

A hedonic test was performed as described by (24). A semitrained panel of 30 mothers from the University of Makerere was used to evaluate the porridge. Evaluation was according to colour, aroma, taste, appearance, mouth feel and overall acceptability using the nine-point hedonic scale from liked extremely (9) to disliked extremely (1). Each of the panelists sat in an individual booth and was provided with hot porridge samples in plastic disposable cups marked with 3digit random codes. Drinking water to rinse the mouth after each taste was also provided.

\section{Statistical analyzes}

All the results obtained were the mean of three repetitions. Statistical analyzes were performed using IBM SPSS Statistics 23 software using one-way analysis of variance (ANOVA).

\section{RESULTS}

\section{Proximate composition}

The results for proximate are described in Table 2 below. Moisture content of the banana composite flours ranged from $9.90 \%$ in formulation B to $10.97 \%$ in formulation E. The banana composite flour had protein content in the range of 20.88 in formulation 60B:35S:05A to $26.08 \%$ in formulation 50B:35S:15A. Sample F recorded the highest protein digestibility of $86.26 \%$ while sample D had $70.9 \%$ as the lowest. The fat content of the composites was relatively low ranging from $6.17 \%$ in formulation $A$ to $7.8 \%$ in formulation $\mathrm{E}$. The fat content increased with an increase in soybean and grain amaranth. The highest fiber content recorded was $3.36 \%$ in formulation $\mathrm{F}$ and the lowest was $2.55 \%$ in formulation D. It was observed that the ash content of the flour samples ranged from $3.9 \%$ in formulation C to $4.2 \%$ in formulation B. The carbohydrate content ranged from $48.18 \%$ in sample $\mathrm{F}$ to $55.21 \%$ in sample B. The energy content was between $363.67 \mathrm{kcal} / 100 \mathrm{~g}$ in sample $\mathrm{A}$ and $368.43 \mathrm{kcal} / 100 \mathrm{~g}$ in sample E.

TABLE 2 : Proximate Composition for the Banana Based Weaning Flour

\begin{tabular}{ccccccccc}
\hline $\begin{array}{c}\text { Sample } \\
\text { code }\end{array}$ & $\begin{array}{c}\text { Crude } \\
\text { Fat (\%) }\end{array}$ & $\begin{array}{c}\text { Moisture } \\
\text { content (\%) }\end{array}$ & $\begin{array}{c}\text { Defatted } \\
\text { Fiber (\%) }\end{array}$ & $\begin{array}{c}\text { Crude } \\
\text { Protein (\%) }\end{array}$ & $\begin{array}{c}\text { Protein } \\
\text { digestibility }\end{array}$ & Ash (\%) & $\begin{array}{c}\text { Carbohydrate } \\
\text { (\%) }\end{array}$ & $\begin{array}{c}\text { Energy } \\
\text { (kcal/100g) }\end{array}$ \\
\hline A & $6.17 \pm 0.6 \mathrm{a}$ & $9.98 \pm 0.2 \mathrm{a}$ & $2.82 \pm 0.1 \mathrm{a}$ & $22.22 \pm 3 \mathrm{ab}$ & $79.27 \pm 3.66 \mathrm{a}$ & $3.99 \pm 0.1 \mathrm{a}$ & $54.81 \pm 3.1 \mathrm{a}$ & $363.67 \pm 1 \mathrm{a}$ \\
$\mathrm{B}$ & $6.7 \pm 0.9 \mathrm{ab}$ & $9.90 \pm 0.7 \mathrm{a}$ & $3.13 \pm 0.2 \mathrm{a}$ & $20.88 \pm 0.7 \mathrm{a}$ & $76.58 \pm 3.84 \mathrm{ab}$ & $4.2 \pm 0.1 \mathrm{ab}$ & $55.21 \pm 1.1 \mathrm{a}$ & $364.7 \pm 3.1 \mathrm{a}$ \\
$\mathrm{C}$ & $6.5 \pm 0.1 \mathrm{a}$ & $10.2 \pm 1.0 \mathrm{a}$ & $2.9 \pm 0.3 \mathrm{ab}$ & $22.0 \pm 1.7 \mathrm{ab}$ & $74.36 \pm 2.57 \mathrm{ab}$ & $3.9 \pm 0.1 \mathrm{ab}$ & $54.4 \pm 2.1 \mathrm{~b}$ & $364.4 \pm 2.4 \mathrm{a}$ \\
$\mathrm{D}$ & $7.0 \pm 0.1 \mathrm{ab}$ & $10.3 \pm 0.5 \mathrm{a}$ & $2.6 \pm 0.2 \mathrm{ab}$ & $21.7 \pm 1.3 \mathrm{ab}$ & $70.90 \pm 3.19 \mathrm{ab}$ & $96 \pm 0.1 \mathrm{ab}$ & $54.44 \pm 1.72 \mathrm{~b}$ & $367.55 \pm 0.96 \mathrm{a}$ \\
$\mathrm{E}$ & $7.80 \pm 0.58 \mathrm{~b}$ & $10.97 \pm 0.44 \mathrm{a}$ & $2.73 \pm 0.08 \mathrm{ab}$ & $25.26 \pm 0.17 \mathrm{ab}$ & $73.98 \pm 2.61 \mathrm{ab}$ & $3.94 \pm 0.02 \mathrm{bc}$ & $49.31 \pm 0.28 \mathrm{~b}$ & $368.43 \pm 4.70 \mathrm{a}$ \\
$\mathrm{F}$ & $7.77 \pm 0.78 \mathrm{~b}$ & $10.53 \pm 0.79 \mathrm{a}$ & $3.36 \pm 0.34 \mathrm{~b}$ & $26.08 \pm 0.42 \mathrm{~b}$ & $86.26 \pm 2.52 \mathrm{~b}$ & $4.08 \pm 0.05 \mathrm{c}$ & $48.18 \pm 1.09 \mathrm{~b}$ & $366.98 \pm 7.23 \mathrm{a}$ \\
\hline
\end{tabular}




\section{Physical properties}

The physical composition for the banana based weaning flour is described in Table 3. Bulk density of the banana based weaning flour ranged from $0.63-0.68 \mathrm{~g} / \mathrm{ml}$ and it reduced with reduction in the banana content.
Foaming capacity of the composite flours ranged from $24 \%$ in formulation $\mathrm{C}$ to $37.27 \%$ in formulation $\mathrm{E}$. The water absorption capacity ranged from 175.82-185.13\% while swelling power was reported to increase from $7.89 \%$ in sample E to $8.32 \%$ in sample B.

TABLE 3 : Physical Composition for the Banana Based Weaning Flour

\begin{tabular}{ccccc}
\hline $\begin{array}{c}\text { Sample } \\
\text { code }\end{array}$ & $\begin{array}{c}\text { Bulk density } \\
(\mathbf{g} / \mathbf{m l})\end{array}$ & $\begin{array}{c}\text { Foaming capacity } \\
\mathbf{( \% )}\end{array}$ & $\begin{array}{c}\text { Swelling power } \\
\mathbf{( \% )}\end{array}$ & $\begin{array}{c}\text { Water Absorption capacity } \\
(\%)\end{array}$ \\
\hline A & $0.63 \pm 0.0001^{\mathrm{a}}$ & $32.45 \pm 0.02^{\mathrm{a}}$ & $8.13 \pm 0.16^{\mathrm{a}}$ & $175.82 \pm 11.00^{\mathrm{a}}$ \\
B & $0.66 \pm 0.0003^{\mathrm{a}}$ & $31.38 \pm 0.87^{\mathrm{b}}$ & $8.32 \pm 0.03^{\mathrm{a}}$ & $185.13 \pm 1.28^{\mathrm{a}}$ \\
C & $0.68 \pm 0.0005^{\mathrm{a}}$ & $24.00 \pm 0.45^{\mathrm{bc}}$ & $8.11 \pm 0.13^{\mathrm{a}}$ & $182.27 \pm 4.61^{\mathrm{a}}$ \\
D & $0.64 \pm 0.0005^{\mathrm{b}}$ & $30.07 \pm 0.28^{\mathrm{bc}}$ & $7.98 \pm 0.11^{\mathrm{a}}$ & $180.72 \pm 7.05^{\mathrm{a}}$ \\
E & $0.63 \pm 0.0005^{\mathrm{c}}$ & $37.27 \pm 0.33^{\mathrm{c}}$ & $7.89 \pm 0.44^{\mathrm{a}}$ & $176.56 \pm 8.00^{\mathrm{a}}$ \\
F & $0.63 \pm 0.0014^{\mathrm{d}}$ & $28.45 \pm 1.82^{\mathrm{d}}$ & $8.49 \pm 0.11^{\mathrm{a}}$ & $180.00 \pm 0.39^{\mathrm{a}}$ \\
\hline
\end{tabular}

\section{Pasting properties}

The pasting temperature was in the range $78.28-79.13^{\circ} \mathrm{C}$ as show in Table 4 . The peak viscosity value ranged from 1241.5 to $2117 \mathrm{cP}$ with formulation A having the highest peak viscosity and formulation $\mathrm{F}$ having the lowest.
The setback viscosity ranged from $790 \mathrm{cP}$ in formulation $\mathrm{B}$ to $1117 \mathrm{Cp}$ in formulation $\mathrm{E}$. The final viscosity ranged from $1867 \mathrm{cP}$ in sample $\mathrm{F}$ to $2547 \mathrm{cP}$ in sample A. Samples $\mathrm{A}$ and $\mathrm{B}$ took less time (5.33 minutes) to reach maximum viscosity.

TABLE 4 : Pasting Properties for the Banana Based Weaning Flour

\begin{tabular}{|c|c|c|c|c|c|c|c|}
\hline $\begin{array}{l}\text { Sample } \\
\text { code }\end{array}$ & $\begin{array}{c}\text { Peak } \\
\text { viscosity }(c P)\end{array}$ & $\begin{array}{c}\text { Trough } \\
\text { viscosity }(c P)\end{array}$ & $\begin{array}{c}\text { Breakdown } \\
\text { viscosity }(c P)\end{array}$ & $\begin{array}{c}\text { Final } \\
\text { viscosity }(c P)\end{array}$ & $\begin{array}{c}\text { Setback } \\
\text { viscosity }(c P)\end{array}$ & $\begin{array}{c}\text { Peak } \\
\text { time(cP) }\end{array}$ & $\begin{array}{c}\text { Pasting } \\
\text { temperature(cP) }\end{array}$ \\
\hline A & $2117.0 \pm 70.71^{\mathrm{a}}$ & $1603.5 \pm 37.48^{\mathrm{a}}$ & $513.5 \pm 33.23$ a & $2547.5 \pm 38.8^{\mathrm{a}}$ & $944.00 \pm 1.41^{\text {a }}$ & $5.33 \pm 0.00 \mathrm{a}$ & $79.13 \pm 0.04 \mathrm{a}^{\mathrm{a}}$ \\
\hline B & $1738.5 \pm 48.79 b$ & $1423.0 \pm 14.14 \mathrm{~b}$ & $315.5 \pm 62.93$ a & $2213.0 \pm 56^{b}$ & $790.00 \pm 70.7 \mathrm{ab}$ & $5.33 \pm 0.00 \mathrm{a}$ & $78.68 \pm 0.67 \mathrm{a}$ \\
\hline $\mathrm{C}$ & $1623.0 \pm 11.31^{b c}$ & $1347.5 \pm 7.78^{b}$ & $275.5 \pm 3.54 \mathrm{ab}$ & $2319.5 \pm 10^{\mathrm{bc}}$ & $972.00 \pm 2.83^{b c}$ & $5.93 \pm 0.00$ a & $79.10 \pm 0.00 \mathrm{a}$ \\
\hline $\mathrm{D}$ & $1942.0 \pm 1.410^{\mathrm{bc}}$ & $1483.5 \pm 3.54 \mathrm{~b}$ & $458.5 \pm 2.1 \mathrm{ab}$ & $2516.0 \pm 11.31 \mathrm{bc}$ & $1032.5 \pm 7.78^{\mathrm{bcd}}$ & $5.37 \pm 0 \mathrm{ab}$ & $78.28 \pm 0.04 \mathrm{a}$ \\
\hline E & $1704.5 \pm 143.5^{\mathrm{cd}}$ & $1347.0 \pm 82 \mathrm{bc}$ & $357.5 \pm 61 \mathrm{bc}$ & $2464.5 \pm 13.3^{c}$ & $1117.5 \pm 57.2 \mathrm{~cd}$ & $5.63 \pm 0.3 \mathrm{~b}$ & $79.08 \pm 0.04 \mathrm{a}$ \\
\hline $\mathrm{F}$ & $1241.5 \pm 23.34 \mathrm{~d}$ & $1029.5 \pm 21.9 c$ & $212.0 \pm 1.41^{\mathrm{c}}$ & $1867.5 \pm 28.9 \mathrm{c}$ & $838.00 \pm 7.07 \mathrm{~d}$ & $6.57 \pm 0.05^{c}$ & $79.08 \pm 0.04 \mathrm{a}$ \\
\hline
\end{tabular}

\section{Sensory analysis}

The formulation with the least amount of banana flour (F50B:35S:15A) was most preferred for appearance, color, texture and aroma while the formulation with the highest banana content (A-60B:30S:10A) was most preferred for mouthfeel and taste. However, the panel had a higher overall acceptability preference for porridge from formulation $D$ (55B:35S:10A).
All the rating scores for the sensory attributes were 6 and above indicating good sensory acceptance. The results in Table 1 show that for appearance, color, texture, aroma, mouthfeel, taste and overall acceptability, the mean scores of the formulated porridges did not differ significantly $(\mathrm{p}<0.05)$.

TABLE 5 : Mean Scores for the Sensory Attributes of the Banana Based Weaning Flour

\begin{tabular}{cccccccc}
\hline $\begin{array}{c}\text { Sample } \\
\text { code }\end{array}$ & Appearance & Color & Texture & Aroma & Mouthfeel & Taste & $\begin{array}{c}\text { Overall } \\
\text { acceptability }\end{array}$ \\
\hline A & $6.37 \pm 1.43^{\mathrm{a}}$ & $6.17 \pm 1.64^{\mathrm{a}}$ & $6.80 \pm 1.13^{\mathrm{a}}$ & $6.63 \pm 1.47^{\mathrm{a}}$ & $6.90 \pm 1.54^{\mathrm{a}}$ & $7.0 \pm 1.39^{\mathrm{a}}$ & $6.77 \pm 1.46^{\mathrm{a}}$ \\
B & $6.70 \pm 1.69^{\mathrm{a}}$ & $6.77 \pm 1.80^{\mathrm{a}}$ & $6.70 \pm 1.26^{\mathrm{a}}$ & $6.67 \pm 1.47^{\mathrm{a}}$ & $6.53 \pm 1.72^{\mathrm{a}}$ & $5.93 \pm 2.03^{\mathrm{a}}$ & $6.53 \pm 1.53^{\mathrm{a}}$ \\
C & $6.33 \pm 1.56^{\mathrm{a}}$ & $6.17 \pm 1.44^{\mathrm{a}}$ & $6.37 \pm 1.50^{\mathrm{a}}$ & $6.23 \pm 1.50^{\mathrm{a}}$ & $6.67 \pm 1.09^{\mathrm{a}}$ & $6.63 \pm 1.52^{\mathrm{a}}$ & $6.63 \pm 1.38^{\mathrm{a}}$ \\
D & $6.60 \pm 1.55^{\mathrm{a}}$ & $6.53 \pm 1.57^{\mathrm{a}}$ & $6.57 \pm 1.19^{\mathrm{a}}$ & $6.60 \pm 1.25^{\mathrm{a}}$ & $6.67 \pm 1.40^{\mathrm{a}}$ & $6.77 \pm 1.25^{\mathrm{a}}$ & $7.07 \pm 1.31^{\mathrm{a}}$ \\
E & $6.50 \pm 1.53^{\mathrm{a}}$ & $6.60 \pm 1.38^{\mathrm{a}}$ & $6.77 \pm 1.04^{\mathrm{a}}$ & $6.30 \pm 1.54^{\mathrm{a}}$ & $6.80 \pm 1.73^{\mathrm{a}}$ & $6.60 \pm 1.45^{\mathrm{a}}$ & $6.77 \pm 1.66^{\mathrm{a}}$ \\
F & $6.8 \pm 1.56^{\mathrm{a}}$ & $6.83 \pm 1.74^{\mathrm{a}}$ & $6.87 \pm 1.46^{\mathrm{a}}$ & $6.7 \pm 1.55^{\mathrm{a}}$ & $6.80 \pm 1.50^{\mathrm{a}}$ & $6.91 \pm 1.51^{\mathrm{a}}$ & $6.8 \pm 1.63^{\mathrm{a}}$
\end{tabular}




\section{DISCUSSION}

\section{Proximate composition}

Moisture content is an important parameter in flours which significantly affects its shelf life. Flour products with moisture content less than $13 \%$ are more stable from moisture dependent deterioration (21) and this makes the banana based weaning flour moisture stable since the range is between 9 and 11 . Protein is one of the most important nutrients in weaning foods. The reason for the increase in protein could be attributed to an increase in grain amaranth which contains superior quality protein 13.56-18.4 g/100g with high lysine and essential amino acid (25). The higher rate of protein digestibility in sample $\mathrm{F}$ could be attributed to the high content of grain amaranth since it is said to have digestibility as high as $80 \%$ (25). The higher percentage of digestibility in sample $\mathrm{F}$ means that the proteins in $\mathrm{F}$ are more readily available to body of the infant as compared to proteins in the rest of the samples. Fat content plays a big role in shelf life stability in terms of the onset of rancidity (26). The crude fat content of the composite porridges is within the range of values $(8.33 \%$ to $10.60 \%$ ) reported for crude fat contents from soybean and sesame by (27). The higher fiber content recorded in sample F could be attributed to the high content of soybean and grain amaranth since they are both known to have high values of fiber. Ash content represents the total mineral content in foods. The ash content in the food of infant should be relatively low and this helps in maintaining the normal balance of the body, relieves load of the kidneys and reduces kidney injury so that the infant can grow healthy. The Carbohydrate content reduced with increased addition of soybean and grain amaranth and reduction in the banana content. This is because soybean contains less amounts of carbohydrate while grain amaranth completely has no carbohydrate. The high energy content is advantageous in the formulation of breakfast cereal and complementary foods (21). The energy value for the banana composite flours was quite lower than the minimum energy (483.9kcal/100g) recommended in the Codex Alimentarious Standards for weaning/ follow up foods (28).

\section{Physical composition}

Relatively low bulk density of the flours is desirable in infant food production. The lower the bulk density, the higher the amount of flour particles that can bind together leading to higher energy values (29). The high values of foaming capacity were attributed to the high protein content in soybean and grain amaranth. These results do not differ from the report by (30) with $23.5 \%$ - $65.0 \%$ for the inclusion of Bambara ground nut flour in plantain. The ability of the composite flours to absorb water reduced with a reduction in the content of banana flour.
This may be attributed to the reduction in carbohydrate content and increased protein content as carbohydrates have been reported to greatly influence the absorption capacity of foods (31). Swelling power increased with inclusion of more banana flour in the samples. Swelling power is the ability of the flour particles to hydrate and increase in size under excess water conditions.

\section{Pasting properties}

The low pasting temperature in sample D indicates that it will require less energy to cook as compared to the other samples. Pasting temperature provides an indication of the minimum temperature required to cook a given sample (32). The high peak viscosity in formulation A could be attributed to the high proportion of banana flour which has high starch content. Set back viscosity indicates gel stability and the potential for retro gradation (33). Both the trough and breakdown viscosity increased with increased introduction of banana flour. Final viscosity indicates the ability of the starch to form a viscous paste or gel after cooking and cooling (23). The high viscosity in sample A could be attributed to the high proportion of banana flour that has high starch content. Samples A and B took less time (5.33 minutes) to reach maximum viscosity; this might be due to the high rate of absorption and swelling of starch granules.

\section{Sensory composition}

The formulation with the least amount of banana flour was most preferred for appearance, color, texture and aroma while the formulation with the highest banana content was most preferred for mouthfeel and taste. The aroma, taste and mouthfeel could be attributed to the presence of soybean in the composition. However, the panel had a higher overall acceptability preference for porridge from formulation $\mathrm{D}$ most probably due to reduction in the banana content and the increased soybean content. All the rating scores for the sensory attributes were 6 and above indicating good sensory acceptance.

\section{Optimum formulation for ingredient proportions}

The most desired formulation was 54.4B:35S:10.6A. The desired formulation had a gross energy of $366.6 \mathrm{Kcal}$, protein content of $23.2 \%$, digestibility of $70 \%$ and acceptability of 6.8. The gross energy of $366.6 \mathrm{Kcal}$ for the optimum proportion was quite low compared to the recommended energy for weaning children. Luckily enough, the energy is usually supplemented by breast milk and other foods being fed to the child. The protein content of $23.2 \%$ is in the range recommended for weaning children and their digestibility is high above $70 \%$ making it healthier for the infant. Acceptability of 6.8 means the porridge is acceptable to the community hence making the banana based weaning flour good flour for the infants between 6-24 months of age.

TABLE 6 : Optimum Formulation for the Banana Based Weaning Flour

\begin{tabular}{cccccccc}
\hline Banana & soybean & Grain amaranth & Energy & Protein & IVPD & acceptability & Desirability \\
\hline 54.40 & 35.00 & 10.60 & 366.628 & 23.1484 & 78.9679 & 6.8081 & 0.5250 \\
\hline
\end{tabular}




\section{CONCLUSION}

This study demonstrated that incorporation of soybean and grain amaranth flour into banana flour significantly $(\mathrm{P}<0.05)$ enhanced its sensory quality and improved on its nutritional quality by lowering the viscosity, thereby improving its protein content and energy density. The energy content of the banana based weaning flour was low compared to the recommended energy for weaning children but this is supplemented by breast milk and other foods that are given to the child. The banana based weaning flour was acceptable by the community, making it desirable for infants between 6-24 months of age.

\section{ACKNOWLEDGEMENT}

This work was supported by the RELOAD (Reducing Postharvest Losses, Adding Value to agricultural products) project.

\section{REFERENCES}

[1] Food and Agricultural Organisation. Agriculture in Sub-Saharan Africa: Prospects and challenges for the next decade. 2016;181(November 1947).

[2] Uganda Bureau of Statistics. Uganda Demographic and Health Survey Key Indicators Report, Kampala, Uganda. 2017;(March).

[3] Ministry of Agriculture Animal Industry and Fisheries. Agricultural Sector Strategic Plan 2015/16-2019/20. 2019;(April 2016).

[4] Steur H De, Odongo W, Gellynck X. Applying the food technology neophobia scale in a developing country context. A case-study on processed matooke (cooking banana) fl our in Central Uganda. 2016; 96:391-3.

[5] Adewaleo.o., Afam I.O and Patrick F. DRYING KINETICS OF BANANA (Musa spp.). 2015;40(June):374-81.

[6] Muranga FI, Nabugoomu F, Katebarirwe JG. Effect of optimal incorporation of hybrid banana flours on acceptability of soy fortified banana flour-based products. African J Biotechnol. 2011;10(85):1978895.

[7] Doymaz I. The kinetics of forced convective airdrying of pumpkin slices. J Food Eng. 2007;79(1):243-8.

[8] Gomez AA., Ferreira M., Pimentel T. Bread with flour obtained from green banana with its peel as partial substitute for wheat flour: Physical, chemical and microbiological characteristics and acceptance. 2016;23(5):2214-22.

[9] Fasolin LH, Almeida GC De, Castanho PS, Nettooliveira ER. Biscoitos produzidos com farinha de banana: avaliações química, física e sensorial. 2007;27(3):524-9.

[10] Reschke C, Lima S, Maciel VT, Souza ML De, Furtado CDM, Carvalho AV. Stability of porridge pre-mixture made with Brazil nut flour and green banana flour with and without milk powder. 2014;34(3):585-90.

[11] Daniel C. THE EFFECTS OF MATURITY AND DRYING METHODS ON THE PROXIMATE COMPOSITION AND PASTING PROPERTIES OF Department of Food Science and Technology College of Food Science and Human Ecology. 2010.
[12] Lokuruka M. Effects of processing on soybean nutrients and potential impact on conumer health: An overview. 2011;11(4).

[13] Tukamuhabwa P, Obaa B, Obua T, Namara M, Okii D, Kabayi P, et al. STATUS OF SOYBEAN PRODUCTION AND IMPACT INDICATORS OF NEW SOYBEAN VARIETIES IN UGANDA. 2017.

[14] Muyonga JH, Andabati B, Ssepuuya G. Effect of heat processing on selected grain amaranth physicochemical properties. 2013;

[15] Muyonga J, Ugen M, Bisikwa J, Nakimbugwe D, Masinde D, Muyinda A, et al. Promoting Production and Utilization of Grain Amaranth for Improved Nutrition and Health in Uganda. Annual Progress Report-Narrative and Appendices. 2011;

[16] Sharma A. STUDIES ON DRYING CHARACTERTICS OF GREEN BANANA FOR PRODUCTION OF BANANA FLOUR. 2012.

[17] Bradley RL. Moisture and Total Solids Analysis. Department of Food Science, University of Wisconsin, Madison, WI 53706, USA. [Internet]. 2010. 85-104 p. Available

from: http://link.springer.com/10.1007/978-1-44191478-1_6

[18] Force PT. AOAC INTERNATIONAL FINAL REPORT AND EXECUTIVE SUMMARIES FROM THE AOAC INTERNATIONAL Presidential Task Force on Best Practices in Microbiological Methodology Contract Deliverable Due to The U.S. Food and Drug Administration Presidential Task Force on. 2006;

[19] Gul S, Safdar M. Proximate Composition and Mineral Analysis of Cinnamon. 2009;8(9):1456-60.

[20] Mezgebo K, Belachew T, Satheesh N. Optimization of red teff flour, malted soybean flour, and papaya fruit powder blending ratios for better nutritional quality and sensory acceptability of porridge. 2018;(February):891-903.

[21] Ohizua ER, Adeola AA, Idowu MA, Adeniyi ST, Raphael A, Simeon OI, et al. Nutrient composition, functional, and pasting properties of unripe cooking banana, pigeon pea, and sweetpotato flour blends. 2017;(August 2016):750-62.

[22] Nicole M, Fei HY, Claver IP. Characterization of Ready-to-Eat Composite Porridge Flours Made by Soy-Maize-Sorghum-Wheat Extrusion Cooking Process. 2010;9(2):171-8.

[23] Wheat Marketing Center. Wheat and Flour Testing Methods. A Guide to Understanding Wheat and Flour Quality. 1998;1-73.

[24] Kaur SA. Development of instant maize porridge using extrusion technology. 2016. 1-77 p.

[25] Akande OA, Nakimbugwe D, Mukisa IM. Optimization of extrusion conditions for the production of instant grain amaranth- - based porridge flour. 2017;(July):1205-14.

[26] Falola AO, Olatidoye OP, Adesala SO, Daramola 0. Effect of Different Processing Methods on Proximate, Functional and Pasting Properties of Plantain Flour. 2015;03(05):522-8. 
[27] Ige MM. Physicochemical, Pasting and Sensory Characteristics of Complementary Foods Formulated from Plantain, Pigeon Pea and Maize Flours. 2017;3(2):7-15.

[28] WHO, FAO. Joint FAO/WHO Food Standards Programme Codex Alimentarius Commission. 1995;(July):3-8.

[29] Steve IO, Babatunde OI. Chemical Compositions and Nutritional Properties of Popcorn-Based Complementary Foods Supplemented with Moringa oleifera Leaves Flour. 2013;2(6):117-32.

[30] Marcel MR. Development of a nutrient dense complementary porridge flour from locally available foods. 2017;
[31] Amagloh FK, Mutukumira AN, Brough L, Weber JL Hardacre A, Coad J. Carbohydrate composition, viscosity, solubility and sensory acceptance of sweetpotato and maize based complementary foods. Food Nutr (Roma). 2013; 1:1-9.

[32] Singh S, Gamlath S, Wakeling L. Original article Nutritional aspects of food extrusion: a review. Int J Food Sci Technol. 2007; 42:916-29.

[33] Teng Y, Liu C, Bai J, Liang J. Mixing, tensile and pasting properties of wheat flour mixed with raw and enzyme treated rice bran. 2015;52(May):3014-21. 